\title{
Deling av kunnskap og kompetanse er ingen selvfølge for deltakere $i$ Yrkesfaglærerløftet
}

\author{
Elin Bø Morud, Klara Lillevik Rokkones \\ Norges teknisk naturvitenskapelige universitet - NTNU
}

\begin{abstract}
Abstrakt
Hensikten med studien er å utvikle ny kunnskap om og forståelse for yrkesfaglærere som tar videreutdanning. Artikkelen presenterer hvordan yrkesfaglærerne opplever at forsknings- og utviklingskompetanse som de opparbeider seg gjennom videreutdanningen bidrar til utvikling av skolens profesjonelle læringsfellesskap og skolen som en lærende organisasjon. Forskning gir god dokumentasjon av hvilke faktorer som fremmer utvikling av profesjonelle læringsfellesskap. Denne studien undersøker om videreutdanningsstudentene erfarer at disse faktorene er til stede, slik at de kan involveres i og får bidra til utvikling av skolens profesjonelle læringsfellesskap. Våre erfaringer tilsier at det ikke er en selvfølge at deltakerne på videreutdanning deler sine erfaringer med kollegaer og ledelse på skolene de representerte. Dette er tilfelle til tross for at deling er en viktig forutsetning for å utvikle profesjonelle læringsfellesskap i skolen. Studien belyser også spørsmålet om hvilke samarbeidsrelasjoner studentene etablerer gjennom FoU-arbeid og hvordan dette bidrar til kompetanseutvikling i læringsfellesskapet. Artikkelen gir innsikt i hvilken støtte og forankring utviklingsprosjekter får i kollegiet og i skolens ledelse.
\end{abstract}

Studien tar utgangspunkt i videreutdanninger i Yrkesfaglærerløftet, og datagrunnlaget omfatter fire fokusgruppeintervju med yrkesfaglærere. I intervjuene spør vi om hvilke erfaringer de har med FoU ved egen skole, og hvordan de samarbeider og deler ny kompetanse og kunnskap med ledelsen, kollegaer og andre samarbeidspartnere. Funnene viser et stort samsvar mellom studentenes erfaringer i hvilke faktorer som er viktige for å utvikle profesjonelle læringsfellesskap. I tillegg ser vi et stort samsvar med de faktorene som forskning og litteratur legger vekt på fremmer utvikling av profesjonelle læringsfellesskap og skoleutvikling. I artikkelen diskuterer vi hvordan funnene i vår studie er koblet til funn i tidligere studier.

Emneord: Profesjonelle læringsfellesskap, Yrkesfaglærere, Videreutdanning, Delingskultur, FoU 


\section{Innledning}

I Kultur for laering (St.meld. nr. 30, 2003/2004) slås det fast at skolelederne har sentrale posisjoner for å bidra til at skoler skal utvikle seg som lærende organisasjoner. Det påpekes at skolene må legge mer vekt på hvordan de kan ivareta sin egen læring. Videre understrekes det at for å møte de nye utfordringene i samfunnet, trenger skolene kompetente lærere og skoleledere som bidrar til å utvikle skolen til en lærende organisasjon. Det krever profesjonelle læringsfellesskap som kan ta ansvar for den tillit de er gitt gjennom sin autonomi i yrkesutøvelsen.

I 2008 kom stortingsmeldingen Kvalitet i skolen (St.mld.31, 2007-2008), som beskriver at målet med kunnskapsdeling i læringsfellesskap er å styrke koblingen mellom lærernes individualiserte kompetanseheving og skolens utvikling, og slik bidra til økt læringsutbytte for elevene. Strategien Kompetanse for kvalitet (Kunnskapsdepartementet, 2015b) retter seg mot lærere som underviser i fellesfag og studiespesialiserende programfag, og her vektlegges betydningen av å utvikle et profesjonelt læringsfellesskap. Et profesjonelt samarbeid mellom lærere oppleves som at det har betydning for skolens kvalitetsutvikling (St.meld. 21, 2016-2017).

Yrkesfaglærerløftet - strategi for fremtidens fagarbeidere kom i 2015 (Kunnskapsdepartementet, 2015a). Ett av målene i Yrkesfaglærerløftet er å gi yrkesfaglærere, faglige ledere og instruktører i bedrift gode muligheter for kompetanseutvikling, og høsten 2017 kunne de første studentene starte på videreutdanning rettet mot utdanningsprogrammene i yrkesfagene. Imidlertid er utvikling av profesjonelle læringsfellesskap fraværende i denne strategien. Dette til tross for en antakelse om at yrkesfaglærere har like god nytte av å delta i profesjonelle læringsfellesskap som lærere som underviser i fellesfag og studieforberedende programfag.

Hensikten med studien som denne artikkelen bygger på er å utvikle ny kunnskap om og forståelse for yrkesfaglærere som tar videreutdanning. Vi spør hvordan de opplever at forskningsog utviklingskompetanse som de opparbeider seg gjennom videreutdanningen bidrar til utvikling av skolens profesjonelle læringsfellesskap og skolen som en lærende organisasjon. Vi ønsker videre å få innsikt i hvilken støtte og forankring FoU-arbeid får i kollegiet og i skolens ledelse. En målsetting er å få innblikk i om videreutdanningene medfører $\varnothing \mathrm{kt}$ kompetanse som igjen bidrar til at deltakerne kan initiere og ta ansvar for ledelse av utviklingsarbeid i egen praksis.

Artikkelen tar utgangspunkt i følgende problemstilling:

Hvordan involveres videreutdanningsstudenter i utviklingen av skolens profesjonelle laringsfellesskap?

Først presenteres den teoretiske rammen om profesjonelle læringsfellesskap som er et grunnlag for studien, samt tidligere forskning knyttet til yrkesfaglæreres læring. Videre vil metode og datamaterialet bli presentert før vi i siste del av artikkelen presenterer våre funn og diskuterer disse. 


\section{Teoretisk ramme}

Vi vil her presentere den teoretiske rammen vi har brukt som utgangspunkt for vår studie.

\section{Utvikling av profesjonelle læringsfellesskap}

Læreres læring er blant annet knyttet til den felles praksisen og de kollektive læringsprosessene som foregår i den enkelte skole, og dette er grunnlaget for at kompetanseutviklingen skal føre til bedre læring hos elevene (Dehlin \& Irgens, 2018). Skoler som utvikler seg til det bedre, er ofte skoler som fremmer læring mellom lærerne gjennom profesjonelle læringsfellesskap (Irgens, 2007; Hargreaves \& Fullan, 2014). Profesjonelle læringsfellesskap er basert på delte verdier om undervisning, felles fokus på elevers læring, samarbeid om utvikling av undervisning og formålsbasert deling av praksiser (Wahlstrom, Louis, Leithwood \& Anderson, 2010).

I en yrkesfaglig kontekst kan dette fortone seg annerledes enn ved studiespesialiserende programområder, men for begge områdene gjelder det at for å oppnå profesjonelle læringsfellesskap, må utviklingsarbeidet være systematisk og målrettet, og det bør legges til rette for observasjon av og refleksjon over undervisning og praksiser (Postholm \& Rokkones, 2013). Delingskultur kjennes ved at lærerne deler sine erfaringer og kunnskaper med sine kollegaer, og dette kan bidra til variert og tilpasset undervisning og læringsarbeid for elevene (Bjørnsrud, 2015).

Skoleledelsen må være tydelige ledere av skolens kompetanseutvikling for at dette skal lykkes (Robinson, 2014; Postholm, 2018). Kompetanseutvikling i et læringsfellesskap er avhengig av berøringspunktet mellom lærernes erfaringsbaserte undervisningskunnskap og den forskningsbaserte kunnskapen de møter (Maugesten \& Mellegård, 2015; Ertsås, 2017). Lærerne må være aktive deltakere i fellesskapet og bidra til utvikling av egen og skolens kunnskapskultur, og det må legges til rette for at lærere som har gjennomført videreutdanning, kan agere som ressurspersoner etter gjennomført videreutdanning (Sekkingstad \& Syse, 2019). Sekkingstad og Syse (2019) etterlyser mer forskning på organisering av videreutdanning for yrkesfaglærere, skoleledelsens rolle som pedagogiske utviklingsledere på kombinerte skoler Slik kan videreutdanningene bidra til utvikling av lærerens helhetlige profesjonsutøvelse som både kunnskapsformidler og kunnskapsdeler (Maugesten \& Mellegård, 2015).

\section{Tidligere forskning på læreres læring}

Interessen for å unders $\varnothing$ ke hvordan videreutdanning kan bidra til læreres læring og skoleutvikling, beskrives i mange studier (eks: Parise \& Spillane, 2010; Postholm \& Rokkones, 2015; Postholm, 2017; Ertsås, 2017). Imidlertid har det vært mindre fokus på å studere yrkesfaglærere og deres forutsetninger for profesjonell utvikling gjennom videreutdanning. En kartlegging gjennomført av NIFU (Aamodt m.fl., 2016), «Kompetanse blant yrkesfaglærere», peker på to utfordringer som har betydning for yrkesfaglæreres kompetanseutvikling. For det første fører brede utdanningsprogrammer til at lærerne opplever forventninger om at de skal undervise i fag som de kjenner at de ikke har tilstrekkelig kompetanse i. Videre beskrives utfordringen med at det skjer hyppige endringer 
innenfor mange fag, slik at det kan være vanskelig å holde seg oppdatert. Yrkesfaglærerne ønsker å utvikle egen kompetanse, og de etterlyser praksisnære opplæringstilbud (Aamodt m.fl., 2016).

Rokkones (2017) har gjort en studie av yrkesfaglærere og deres erfaringer med videreutdanning innenfor strategien Kompetanse for kvalitet (Kunnskapsdepartementet, 2015 a) og hvilke ønsker de har for videreutdanning. Der kommer det frem at yrkesfaglærere etterspør videreutdanning med fokus på yrkesfaglig fordypning. En annen studie av videreutdanning for yrkesfaglærere fra 2012 viser at teori-praksis-dimensjonen er spesielt viktig, og at det er avgjørende å legge til rette for transformasjon av kunnskap mellom videreutdanning og praksisarena (Rokkones \& Postholm, 2012a). Sekkingstad og Syse (2019) har studert betingelsene for å lykkes med skolebaserte videreutdanninger for yrkesfaglærere, og de finner at det bør legges til rette for utprøving og refleksjon over praksis i grupper på samlinger, i nettverk mellom samlingene og som eksamensform for å bidra til kompetanseutvikling. Forsknings- og utviklingsarbeid (FoU-arbeid) er en arbeidsform som kan fungere som et bindeledd mellom læreres læring og deres yrkesutøvelse (Rokkones \& Postholm, 2012b).

En studie av organisasjonsutvikling i skolen i en australsk, yrkesfaglig kontekst viser at for å lykkes med læring og endring i skolen må planleggingen av yrkeslærernes profesjonelle utvikling være sterkt kontekstualisert. Yrkesfaglærernes læringsbehov og analyse av spenninger og rammefaktorer som kan påvirke prosessene må ligge til grunn (Bound, 2011). Studien beskriver hvordan arbeidsstrukturer, kulturer og historier skaper muligheter og begrensninger for profesjonell læring og utvikling. Samarbeid med arbeidslivet er en kontekst som også innlemmes i utviklingen av et profesjonelt læringsfelleskap for yrkesfaglærere. Andersson og Köpsén (2015) har gjennomført en svensk studie som omfatter yrkesfaglig videreutvikling for lærere. Studien fremhever viktigheten av å ta utgangspunkt i yrkesfaglærernes yrke og lærerrollen for å utvikle en dobbel profesjonalitet, samt at vilkårene for yrkesfaglærernes kompetanse i eget undervisningsfaget skiller seg fra andre grupper av lærere.

\section{Profesjonsutvikling i spenningsfeltet mellom individ og fellesskap}

Utvikling av profesjonelle læringsfellesskap er gjerne knyttet til begrepet livslang laring og forståelsen av skolen som en larende organisasjon. Begge begrepene står sentralt i styringsdokumenter og politiske målsettinger i dag (eks: Utdanningsdirektoratet, 2009; NOU 2019:12). Livslang læring i skolesektoren omfatter læreres deltakelse i etter- og videreutdanning (Grutle, 2019). Yrkesfaglærerløftet er et eksempel på en strategi som skal legge til rette for livslang læring.

Begrepet en laerende organisasjon brukes i mange sammenhenger, men som grunnlag for å skape en lærende organisasjon tar vi i denne studien utgangspunkt i Senge (2006). Han tar utgangspunkt i fem disipliner som grunnlaget for å skape lærende organisasjoner: personlig mestring, mentale modeller, felles visjon og gruppelaring, og systemisk tenking, De fem disiplinene er kjernen av hva alle deltakere i en lærende organisasjon selv må jobbe for å utvikle og bidra til organisasjonens læring. For å utvikle skolen som lærende organisasjon vil dette innebære at lærerne må utvikle seg både som individer og som gruppe. For lærere kan denne utviklingen skje gjennom 
videreutdanning og FoU-arbeid. Personlig mestring og mentale modeller vil i denne sammenheng dreie seg om forberedelse til å kunne kartlegge, planlegge, gjennomføre, dokumentere og vurdere FoU-arbeid i egen praksis. De to neste kategoriene vil dreie seg om hvordan studentene etablerer og samarbeider med egen skole om felles visjon og gruppelaring.

Ifølge Senge (2000) er det vesentlig for deltakerne i en lærende organisasjon å ha en felles visjon. Felles visjon og gruppelæring omhandler i denne sammenheng hvordan studentene etablerer samarbeid og deling med ledelse, kollegaer og andre aktører for å nå felles målsettinger. Reell og varig endring krever at lærerne og lederne i skolen endrer sitt tankesett. Et virkemiddel for å oppnå dette er at lærere får anledning til å delta på etter- og videreutdanning. Skoleledere har et ansvar for hele organisasjonen og å berede skolen til utvikling. Gjennom systemisk tenking står de for helhetstenkingen mellom disiplinene og må legge til rette for at skolen har den nødvendige kompetansen for å kunne gi elevene et best mulig tilbud.

Kompetansehevingen enkeltlærere får gjennom formell videreutdanning, kan brukes som en ressurs for å bidra til faglig utvikling dersom ledelsen og skolen ser de muligheter dette kan gi (Grutle, 2018). Det er ledelsen i skolen som må legge til rette for en individuell læring som kan bidra inn i den kollektive læringen i skolen (Glosvik, 2010). Det vil innebære at skoleledere har større behov for systemisk tenking og helhetstenking i forhold til kompleksiteten de vil møte som skoleledere. Senge (2000) peker på at i teamsamarbeid er kollektiv læring både en betingelse for, og en konsekvens av, samspillet mellom menneskene i teamet.

Yrkesfaglærerne bringer med seg personlige teorier som omfatter overbevisning og verdier, kunnskaper, ferdigheter og praksiser som følge av disse personlige teoriene, og en formening om hva elevene skal sitte igjen med som utbytte av undervisningen (Robinson, 1993). Ertsås og Irgens (2012) fremhever at forholdet mellom teori og praksis er sentralt i utviklingen av profesjonelle yrkesutøvere, i denne sammenheng utvikling av yrkesfaglærerens kompetanse som deltaker i videreutdanning. Profesjonell utvikling innebærer at yrkesfaglæreren må kunne lære på grunnlag av sin egen praksis, det innebærer å begrunne sin undervisningspraksis teoretisk og sette den inn i en større sammenheng. Målet er at studentene gjennom en aktiv prosess skal kunne anvende og konstruere teori i egen kompetanseutvikling.

Postholm og Jacobsen (2011) beskriver at hovedhensikten med forsknings- og utviklingsarbeid (FoU) i skolen er at lærerne, med et forskerblikk på egen praksis, skal kunne videreutvikle undervisning kontinuerlig med mål om bedre læring for elevene. Begrepet FoU henspiller imidlertid på at det er (minst) to prosesser som foregår samtidig, praksis skal både utforskes og utvikles (Postholm \& Moen, 2009). Dette krever at studentene i samarbeid med medstudenter, egne kollegaer og skolens ledelse, etablerer utviklingsfellesskap med mål om felles forståelse for praksiser som skjer. FoU innebærer at lærerne retter et forskende blikk mot læringsaktiviteter i klasserommet, og dette må være et systematisk arbeid (Tiller, 2006). I skolen kan lærerutdannere, lærere og skoleledere sammen utvikle en felles forståelse av de etablerte praksiser som utspiller seg (Senge, 2000).

Larelyst - tidlig innsats og kvalitet i skolen (St.mld. 21, 2016-2017) har som mål å legge til rette for god kompetanseutvikling på skolenivå og bidra til å videreutvikle et profesjonelt læringsfellesskap mellom lærere og skoleledere. Dette er et grunnlag for FoU-arbeidet i videre- 
utdanningene, der lærerne får mulighet til å jobbe med praksisnære FoU-prosjekter med mål om kvalitetsutvikling på egen skole.

\section{Metode \\ Om intervju som metode}

Studien er en kvalitativ intervjustudie (Kvale, Brinkmann, Anderssen, \& Rygge, 2015), og ble gjennomført som fokusgruppeintervju. Ifølge Malterud (2011) fungerer fokusgruppeintervju godt når du skal få tak i erfaringer, holdninger eller synspunkter i kontekster der mennesker samhandler. Ved å sette sammen studentgrupper på tvers av ulike skoler og programområder er målet å få til en samtale mellom deltagerne om felles erfaringer som de kan bygge videre på i organiseringen og utvikling av egen praksis. I denne studien er vi opptatt av å sammenligne og studere ulike former for samarbeid mellom studenter, kollegaer og skolens ledelse.

Et fokusgruppeintervju blir ledet av forskeren, hvor forskernes oppgave er å skape en god og åpen atmosfære slik at alle får lyst til å uttale seg og slik at mange forskjellige synspunkter om emnet som er i fokus, kommer frem i intervjuet (Chrzanowska, 2002). Det er ikke et mål for fokusgruppeintervjuet at deltakerne skal komme frem til enighet eller løsninger på spørsmålene som diskuteres, men forskeren kan også oppleve at deltakerne har en felles eller en kollektiv oppfattelse av teamet som er i fokus (Kamberelis \& Dimitriadis, 2011). I det tradisjonelle fokusgruppeintervjuet har imidlertid intensjonen vært å innhente informasjon uten nødvendigvis å ha som uttalt målsetting å forbedre forhold og situasjoner (Fontana \& Frey, 2000).

\section{Datainnsamling}

Deltakelse og gjennomføring av FoU-arbeid er vektlagt i videreutdanningene vi tilbyr ved NTNU. Vår studie er gjennomført med studenter fra tre videreutdanningsemner på NTNU: Yrkesfaglig fordypning - yrkesrelevant opplaring modul 1 og 2, Veiledning og relasjonskompetanse, alle på 15 studiepoeng. Studietilbudene er utviklet med et utgangspunkt $\mathrm{i}$ at fagopplæring foregår både på skole og i bedrift, og samspillet mellom skole og bedrift er derfor et helt sentralt element i studiene. Planlegging og gjennomføring av FoU-arbeid i egen praksis har vært sentralt innenfor tilbudene, og det har blitt lagt til rette for etablering av samarbeidsprosjekter mellom skole og bedrift/virksomhet. Dette krever at studentene i samarbeid med medstudenter, egne kollegaer og skolens ledelse etablerer utviklingsfellesskap med mål om felles forståelse for praksiser som skjer. Alle har et ansvar for at endring og utvikling skjer ved egen skole

De fire fokusgruppeintervjuene ble gjennomført våren 2019, etter at studentene hadde fullført videreutdanningen. Intervjuene skal gi oss innsikt i hvordan studentene tar i bruk, organiserer og samarbeider med kollegaer og ledelse om gjennomføring av utviklingsarbeid og endringsarbeid i egen praksis. Alle som deltok i intervjuene har deltatt på videreutdanning og samarbeidet om gjennomføring av FoU ved sine egne skoler.

Fokusgruppene omfatter 10 yrkesfaglærere fordelt på fire grupper. De utvalgte gruppene representerer fem yrkesfaglige utdanningsprogram: naturbruk, restaurant- og matfag, helse- og oppvekst- 
fag, bygg- og anleggsteknikk og teknologi og industriell produksjon. De kommer fra både byskoler og distriktskoler med ulik geografisk og demografisk tilhørighet, og det var fem kvinner og fem menn som deltok. Fokusgruppene besto av to grupper med tre studenter og to grupper med to studenter. Det er en gruppestørrelse som er mindre enn det som ofte er anbefalt til fokusgrupper (Malterud, 2011), men med felles erfaringer fra skolekontekst og FoU-arbeid ble det en god dialog om temaene mellom deltagerne i gruppene, slik målet for fokusgruppeintervju er.

Studentene hadde presentert og dokumentert sitt FoU-arbeid, først gjennom en muntlig presentasjon for medstudenter og faglærere og ved semesterets slutt leverte de en eksamenstekst i hvor FoU-arbeidet ble presentert, dokumentert og drøftet opp mot faglitteratur. FoU-oppgavene dannet bakgrunn for utvikling av intervjuguide og gjennomføring av selve intervjusituasjonen. Spørsmålene ble utformet slik at studentene fikk formidle de erfaringene de hadde fătt gjennom sitt eget FoU-arbeid, og hvordan dette var blitt en del av deres praksis på det tidspunktet intervjuet ble gjennomført. Noen av spørsmålene som ble stilt i intervjuene var om studentene kunne si noe om hvordan tema/fokusområde for utviklingsarbeidet ble bestemt og hvordan ledelsen ved skolen involverte seg i FoU-arbeid. Videre ble de bedt om å reflektere over om de opplevde å få den nødvendige støtten for å gjennomføre FoU-arbeid slik dere ønsket å gjøre det. Vi stilte spørsmål om samarbeid med kolleger i egen avdeling om gjennomføring av FoU-arbeidet, og om de samarbeidet med andre aktører i gjennomføring av FoU-arbeidet. Til slutt etterspurte vi også om status for FoU-arbeid i dag - og i hvilken grad det ble implementert i skolens virksomhet.

\section{Dataanalyse, kvalitet og etikk}

Intervjuene er analysert ved å bruke den konstant komparative analysemetoden (Strauss \& Corbin, 1998), som er utviklet innenfor metodologien «grounded theory» (Postholm, 2018; Strauss \& Corbin, 1998). Intervjuene ble transkribert, og vi gjorde først en koding av intervjuene hver for oss for å gjøre en første strukturering av datamaterialet. Etter denne individuelle kodingen satte vi oss sammen og diskuterte den innledende analysen og kom frem til en felles omforent strukturering av datamaterialet. I den videre åpne kodingsprosessen (Strauss \& Corbin, 1998) utviklet vi kategorier med utgangspunkt i kodene (Rennestam \& Wästerfors, 2015). Gjennom analyseprosessen kom vi frem til to hovedkategorier.

Prosjektet er innmeldt og godkjent av NSD, og vi er forpliktet til ikke å publisere personopplysninger. Studien følger de etiske prinsipper om anonymisering (NESH, 2016). Som en del av anonymiseringen blir alle informanter beskrevet som «han», «lærer» og «gruppene», på denne måten er informantenes integritet ivaretatt.

Et forskningsetisk dilemma er at en av forfatterne har deltatt i undervisning og veiledning i dette videreutdanningsemnet. Det betyr at vedkommende ikke kan sies å være utenforstående nøytral forsker (Postholm \& Jacobsen, 2011). Det har derfor vært viktig å være bevisst på dette i analysearbeidet og bruke begrepene fra teorigrunnlaget som kan bidra til å holde en kritisk distanse i analysearbeid og drøftinger. Samtidig vil forskerens kjennskap til studiet fra innsiden kunne sees som en positiv subjektivitet i utformingen av studien, da forskeren kan bidra med en genuin innsikt i utdanningens innhold og intensjon.

Forskningssamarbeidet omfatter alle deler av studien. 


\section{Studiens funn}

Med utgangspunkt i problemstillingen presenterer vi her våre funn om hvordan videreutdanningsstudenter ble involvert i utviklingen av skolens profesjonelle læringsfellesskap. Studiens funn presenteres under kategoriene Delingskultur og FoU-arbeid.

\section{Delingskultur}

\section{Ledelse}

Studien viser at det er ulik interesse og oppfølging fra skolenes ledelse (rektor, ledergruppe, avdelingsledere), men flere opplever at potensialet for å bruke den kompetansen de utvikler, ikke er utnyttet til fulle. Ledelsen er imidlertid positiv når deltakerne informerer om sin deltakelse $\mathrm{i}$ videreutdanning og hvilke arbeidskrav det innebærer, men det kan se ut til at det stopper der. De opplever svake forventinger om deling, det kan i beste fall være at deltakerne får mulighet til en kort presentasjon på et fellesmøte. En gruppe sier at «vi har presentert for avdelinga vår, men ikke for ledelsen». Ledelsen har opplevdes som distansert og har ikke etterspurt innsikt i hvilken kompetanse lærerne har utviklet gjennom videreutdanningen. En gruppe uttrykker «Støtte fra skoleledelsen? Nei!»

En av lærerne beskriver at «det er ingen endringsvilje» i skolen han representerer. Dette kommer også frem i et annet av intervjuene, hvor lærerne forteller at «Egentlig fikk vi bra støtte for det vi skulle prøve ut, men vi har ikke hatt noen oppfølging i forhold til dette».

Ikke alle gruppene har de samme erfaringene. En av gruppene besto av to lærere fra samme skole og som begge har gjennomført to emner i videreutdanningen, og de har jobbet med utvikling av samme FoU-arbeid. De har erfart at FoU-arbeidet og deling av kunnskap og kompetanse fra videreutdanningen har hatt stor innvirkning på skolens organisering av innholdet i programfagene og at rektor har vært en viktig støttespiller. FoU-arbeidet mener de er et godt eksempel på at videreutdanning kan bidra til endring av praksis, og de fremhever at det har medført et tettere samarbeid mellom kollegiet og skolens ledelse. «Han [rektor] var ganske tydelig på at det trengs endring ... men vi ser jo at det er ringvirkninger, og det er positivt for de vi jobber for, og det er jo elevene våre.»

De trekker også frem at muligheten til videreføring av FoU-arbeidet i modul 2 av videreutdanningen ble avgjørende for at de hadde tid til å implementere og jobbe over en lengre periode med endringsarbeidet de igangsatte på sin første videreutdanning.

\section{Kollegaer}

I datamaterialet går det igjen at det er ulike kulturer for deling av kunnskap med kollegaer og ledelse. En av gruppene formidler at «Nei, det har ikke vært noe kultur på skolen vår for deling og presentasjoner, kanskje på et fellesmøte.... Har ikke kultur for sånne ting!». I intervjuene stilte vi også spørsmål om de hadde samarbeid med sine kollegaer i utviklingsarbeidet de gjennomførte. En gruppe, hvor alle kom fra samme skole, sier at kollegaer deltok i FoU- arbeidet sammen med dem og at de har bidratt til videreføring og spredning til andre skoler og bedrifter. «... når vi skulle ha 
utprøving i vår FoU, valgt vi å gjøre det på egen avdeling, og da har vi med våre kollegaer, det har vært greit å samarbeide med de nærmeste ...»

Noen av deltagerne sier også at det er lettere å gjennomføre utviklingsarbeid når de er flere fra samme skole som deltar på videreutdanning sammen. Andre beskriver imidlertid at det er liten interesse fra kollegiet, unntak kan være enkeltpersoner som til gjengjeld viser stor interesse.

Det går frem fra studien at det er ulike rutiner for deling og samarbeid også når det gjelder kollegaer. Det synes heller ikke som om det er klare forventninger fra kollegaene om deling og spredning av ny kunnskap. Det blir litt tilfeldig og gjerne opp til dem som viser interesse og som er tette samarbeidspartnere i utgangspunktet.

\section{Samarbeid med andre}

Uttalelser fra alle gruppene viser at de opplever at FoU-arbeidet fremmet samarbeid og deling mellom medstudenter, også utenom samlingene. Samarbeidet med de andre deltakerne på videreutdanningen trekkes frem som sentralt av alle deltakerne om Læringsfellesskapet som utvikles mellom studentene bidrar til deres faglige utvikling. «Det mest lærerike for meg er faktisk å komme hit og diskutere, prate og lytte til andre. Sånn at du henter opp ideer, får tips om hvordan andre gjør $\operatorname{det} \ldots$.

Dette omfatter erfaringsutveksling gruppene imellom, men også samarbeidet med andre aktører som skoler, bedrifter og opplæringskontor er viktig for studentene. Samarbeidet med bedrifter var et av kravene i videreutdanningen, og vi ser i studien at dette var godt mottatt både av deltakerne og bedriftene. En av studentene forteller at de gjennom dette studiet har utviklet et ukeskurs med opplegg for faglige ledere og veiledere i forbindelse med hospitering i skolen. Dette kurset ble utformet ut fra et $\varnothing$ nske fra bedriftene.

For flere av deltakerne ble praksis $i$ bedrift en viktig arena som de også samarbeidet med i sitt FoU-arbeid. Opplæringskontorer fikk en sentral rolle i datainnsamlingen for flere av FoU-prosjektene, og flere av studentene har opplevd at relasjonen mellom opplæringskontor og lærere har endret seg gjennom dette samarbeidet. «Det er vi som har tatt initiativet igjennom den her hospiteringsperioden [i videreutdanningen] på opplæringskontoret, for å skape den relasjonen.»

Opplæringskontorene kunne bidra med kontakter, hadde oversikt over lærlinger og lærekandidater, og de kunne også på vegne av bedriftene peke på utfordringer i opplæringen som det var $\varnothing$ nskelig at skole og bedrifter samarbeidet om. «Opplæringskontorene er jo positive til at vi egentlig bruker samme verktøyene innenfor vurdering. Vi får noe, faktisk noe å enes om.»

Studiens funn viser at det er stor interesse for å få til et samarbeid mellom skole, opplæringskontor og bedrift. Funnene tyder på at interessen spesielt retter seg mot samarbeid om vurdering innenfor faget yrkesfaglig fordypning. Gjennom sine FoU-arbeid har studentene utviklet prosjekter som er godt etablert, og de uttrykker at det er $\emptyset$ nske om at de videreføres.

\section{FoU-arbeid}

To av gruppene sier at FoU-arbeidet de startet med, vil videreføres og videreutvikles i deres praksis. En gruppe er usikker på hva som skjer videre, de har ingen konkrete planer eller løfter om videre- 
føring på egen skole. Den siste gruppa, som har jobbet med sitt FoU-prosjekt opp mot bedrifter, er usikker i forhold til hva som kan videreføres. De forteller at de opplever at forankringen ved egen skole og i ledelsen er for svak. For å kunne videreføre trenger de tydeligere støtte i egen organisasjon, samt en mer forpliktende avtale med bedriftene om videre samarbeid.

\section{Samarbeid med ledelse og kollegaer}

Erfaringene fra gruppene gir et bilde av at utviklingsarbeidet er ulikt forankret i skolenes ledelse samt i samarbeidet med andre skoler og bedrifter. Vi finner at yrkesfaglærernes motivasjon er tydelig på plass, både for videreføring og videreutvikling. En av studentene uttrykker det på denne måten: «Vi ser muligheten til å videreutvikle vurderingsverktøyet som ble utviklet i YFF til programfagene, vi ser det finnes mange muligheter.»

Studien har bidratt med innsikt i hvordan samarbeid om FoU-arbeid utvikles mellom kollegaer, enkeltlærere, skoleledelse og andre aktører som bedrifter. Videre har vi fått kjennskap til hvordan samarbeidet er med skolens ledelse og FoU-prosjektenes forankring i organisasjonen. Veiledning og prosesser rundt tema i studentenes FoU-arbeid synes å fungere etter målsettingen i videreutdanningsemnene vi har samlet data innenfor. Dataene fra fokusgruppeintervjuene viser også at det er både en kort og en lang vei til å implementere og forankre FoU-prosjekter i egen organisasjon.

Det går frem av intervjuene at deltakelse på videreutdanning som vektlegger FoU-arbeid, ikke automatisk er en satsing på utvikling av kompetanse som skolen etterspør. Det sier heller ikke noe om at deres deltakelse er en del av en plan for skolens FoU-arbeid.

I intervjuene kommer det frem gode eksempler på samarbeid med opplæringskontor og bedrifter om FoU-arbeid. Det har dreid seg om utvikling og utprøving av rutiner og digitaliseringsverktøy for vurdering av faget Yrkesfaglig fordypning. I tillegg har en gruppe i samarbeid med et opplæringskontor startet utvikling av et opplæringstilbud for instruktører og faglige ledere i bedrift som etterspør pedagogisk og yrkesdidaktisk kompetanse i opplæringen av lærlinger i bedrifter. Utgangspunktet var en kartlegging med spørsmål om hva slags kompetanse de ønsket seg i forhold til opplæringen av lærlinger. Kartleggingen gjennomførte de i samarbeid med skoleeier. Deltakere var opplæringskontor og bedrifter, 200 svarte. De sier:

Det er $\emptyset$ nske om et ukekurs i skolen med vektlegging av didaktisk og pedagogisk verktøy sammen med veiledning. Vi tenker videre at det vil være fint for deltakerne til å prøve seg på en undervisningsøkt for en klasse på slutten av kurset ...

Eksemplene som trekkes frem, viser ulike samarbeidsmuligheter med opplæringskontor og bedrifter. Fagfornyelsen vil kreve et tettere samarbeid om opplæringen i skole og bedrift, en mer helhetlig opplæring innenfor de fire årene frem mot fagbrev.

\section{Diskusjon}

Hvordan involveres videreutdanningsstudenter i utviklingen av skolens profesjonelle læringsfellesskap? Problemstillingen og studiens funn er vårt utgangspunkt for diskusjonen. 
Betydningen av delingskultur for utvikling av profesjonelle læringsfellesskap omfatter samarbeid med ledelse, kollegaer og andre samarbeidspartnere som bedrifter/virksomheter som er en viktig del av opplæringen i yrkesfagene (Senge, 2000; Hargreaves \& Fullan, 2014; Bjørnsrud, 2015).

Studien viser at det er ulik interesse og oppfølging fra skolens ledelse (rektor, ledergruppa, avdelingsledere), og studentene beskriver at potensialet for å bruke kompetansen de utvikler ikke utnyttes nok.

Deltakerne opplever at ledelsen er positiv til deres deltakelse i videreutdanning, men det er ikke forventninger til at lærerne bidrar med deling og til skolens utvikling, Skolens ledelse klarer ikke å innlemme lærere som er deltakere på videreutdanning som en ressurs de kan bruke som en del av den systemiske tenkingen om skolens utvikling, slik Senge (2006) tilrår for å utvikle skolen som en lærende organisasjon. Talis-unders $ø$ kelsen $(\mathrm{OECD}, 2014)$ viser også at norske rektorer i noe mindre grad enn sine kollegaer i andre land er aktive i det pedagogiske utviklingsarbeidet. De støtter i litt mindre grad samarbeid mellom lærere om å utvikle ny praksis og tar i noe mindre grad ansvar for å sikre at lærere utvikler undervisningspraksisen sin.

En av rektorene har imidlertid vist stort engasjement og ser hvilke ringvirkninger deltagelse i videreutdanning har får kolleger og elever ved skolen. Det er tydelig at lærerne som jobber ved en skole hvor rektor er aktiv i det pedagogiske utviklingsarbeidet ser hvilken betydning dette har for hele skolen som organisasjon.

Sentrale styringsdokumenter som Kultur for laring (Kunnskapsdepartementet, 2004) og Kompetanse for kvalitet (Kunnskapsdepartementet, 2015a) fremhever skoleledernes sentrale rolle for at skoler skal utvikle seg som lærende organisasjoner og legge til rette for utvikling av profesjonelle læringsfellesskap. Studien har vist at studentene erfarer ulik oppfølging fra skolens ledelse, varierende fra ingen interesse til litt interessert. Felles for alle er at de ikke erfarer at videreutdanningene de har gjennomført, er en del av skolenes endrings- og utviklingsarbeid. Forskning viser at det må legges til rette for at lærerne kan dele sine erfaringer og kunnskaper med kollegaer (Bjørnsrud, 2015) og at skoleledelsen må lede skolens kompetanseutvikling for at dette skal lykkes (Bound, 2011; Robinson, 2014, s.105; Andersson \& Köpsén, 2015; Postholm, 2018).

Utvikling av profesjonelle læringsfellesskap er avhengig av berøringspunktet mellom lærernes erfaringsbaserte undervisningskunnskap og den forskningsbaserte kunnskapen de møter (Bound, 2011; Maugesten \& Mellegård, 2015; Ertsås, 2017). Studien viser at skoleledelsens rolle er viktig som tilrettelegger for at lærerne blir aktive deltakere i fellesskapet og kan bidra til utvikling av skolen som et profesjonelt læringsfellesskap. Det må legges til rette for at lærere som har gjennomført videreutdanning, kan agere som ressurspersoner etter gjennomført videreutdanning (Sekkingstad \& Syse, 2019). Et profesjonelt samarbeid mellom lærere oppleves som at det har betydning for skolens kvalitetsutvikling (St.meld. 21, 2016-2017).

Vektlegging av FoU-arbeid i videreutdanningen har som mål å legge til rette for et samarbeid med skolens ledelse og kollegaer for å bidra aktivt til utvikling av skolen profesjonelle læringsfellesskap (Senge, 2000; Postholm \& Jacobsen, 2011; Rokkones \& Postholm, 2012b). Studien viser variasjon i erfaringer når det gjelder samarbeid om FoU. En gruppe viser til at deres FoU-arbeid og deling av kunnskap fra videreutdanningen har hatt stor innvirkning på skolens organisering av innholdet i programfagene, og at rektor har vært en viktig støttespiller. Det er et 
eksempel som viser at videreutdanning kan bidra til endring av praksis og et tettere samarbeid mellom kollegiet og skolens ledelse. Dette tette samarbeidet mellom grupper av kollegaer er en utvikling av en gruppelaering som er en av de fem disiplinene Senge (2006) viser til som forutsetning for å skape en lærende organisasjon.

I studien trekkes kollegaer frem som tette samarbeidspartnere, og naturlige delingspartnere, for FoU-arbeidet studentene gjennomfører i egen praksis. Det vises også til eksempler der kollegaer har vært deltakere i gjennomføringen av FoU-arbeid ved egen skole. De samme erfaringene beskrives om samarbeid med bedrifter og opplæringskontor. Dette samarbeidet er en kontekst som også må innlemmes i utviklingen for å oppnå et profesjonelt læringsfelleskap for yrkesfaglærere (Bound, 2011). Dette er et eksempel på utviklingen av yrkesfaglærerens doble profesjonalitet (Andersson og Köpsén, 2015). FoU-arbeid er i slike sammenhenger nyttig for begge parter, eksempel på dette er vurdering i faget yrkesfaglig fordypning. I videreutdanningen legges det til rette for at studentene skal erfare personlig mestring gjennom samarbeid med medstudenter om aktuelle tema og problemstillinger til FoU-arbeidet de skal gjennomføre i egen praksis.

Studien viser at det er en utfordring for studentene å etablere et $\varnothing$ nsket samarbeid og deling med ledelsen og kollegaer på skolene (Senge, 2000; 2006; Glosvik, 2010). Flere opplever liten interesse for kompetansen de bringer inn i læringsfellesskapet etter deltagelse i videreutdanningen. De samme erfaringene gjør de også når de etablerer og gjennomfører FoU-arbeidet. De erfarer at FoUarbeidet ikke er godt nok forankret og en del av skolens felles satsing og utviklingsplan. Det er ledelsen i skolen som må legge til rette for en individuell læring som kan bidra inn i den kollektive læringen i skolen (Glosvik, 2010). Det vil innebære at skoleledere har større behov for systemisk tenking og helhetstenking når det gjelder kompleksiteten de vil møte som skoleledere.

Senge (2006) beskriver systemisk tenking som den femte disiplinen som integrerer de fire andre og som står for helhetstenkingen mellom disiplinene. Disiplinene er kjernen av hva alle deltakere $\mathrm{i}$ en lærende organisasjon selv må jobbe med for å utvikle og bidra til organisasjonens læring. Et relevant spørsmål å stille er hvordan kompetansen lærerne utvikler gjennom deltakelse i videreutdanning kan bidra til skolen som en lærende organisasjon. Senge (2000) beskriver at i teamsamarbeid er kollektiv læring både en betingelse for, og en konsekvens av, samspillet mellom menneskene i teamet. FoU-arbeidet studentene gjennomfører i videreutdanningen, er et godt eksempel på en kollektiv læringsprosess som krever samarbeid og en etablert delingskultur for å lykkes. Det er vesentlig for deltakerne i en lærende organisasjon å ha en felles visjon og slik jobbe i fellesskap og dele erfaringer for å nå ulike målsettinger (Senge, 2000). Videreutdanning bør være en del av dette. Senge (2000) beskriver at i skolen kan lærerutdannere, lærere og ledere sammen utvikle en felles forståelse for de etablerte praksiser som utspiller seg. Vi ser at det har gått for kort tid til å konkludere om FoU-arbeidene som er satt i gang i videreutdanningene, videreføres og videreutvikles.

Å se muligheter er sannsynligvis ikke nok for å bidra i læringsfellesskapet, hvis du mangler forankring og støtte i egen organisasjon og kollegiet. Grutle (2018) fremhever betydningen av støtte fra ledelse og kollegaer gjennom praktisk tilrettelegging. Det at ledelsen og kollegaer viser interesse kan også bety mye for de lærerne som deltar i videreutdanninger. 


\section{Oppsummering}

I vår studie stilte vi spørsmål om hvordan videreutdanningsstudenter ble involvert i utviklingen av skolens profesjonelle læringsfellesskap. Studien viser at flere yrkesfaglærere som går på videreutdanning, mener at de kunne vært brukt mer aktivt for å utvikle det profesjonelle læringsfellesskapet i skolen enn det de opplever. Det er et potensiale for at skolens ledelse kan bli mer bevisst på å involvere seg i hvilken kompetanseheving lærere på videreutdanning faktisk får, og hvordan dette kan og bør settes i sammenheng med skolens plan for utvikling og læring. Det er skolens ledelse som må ta hovedansvaret for at skolene skal utvikle seg til å bli lærende organisasjoner og for at hver enkelt lærer skal oppleve seg som en del av et profesjonelt læringsfellesskap. Yrkesfaglærernes ønske om faglig utvikling gjennom å ta videreutdanning - for i neste omgang bidra til deling og utvikling av skolens profesjonelle læringsfellesskap, bør tas på alvor og inngå som en viktig del av skolens utviklingsplan.

Ertsås og Irgens (2012) fremhever at forholdet mellom teori og praksis er sentralt i utviklingen av profesjonelle yrkesutøvere, i denne sammenheng utvikling av yrkesfaglærernes kompetanse. FoU-arbeidene de gjennomfører som en del av videreutdanningen, kan være et viktig virkemiddel for å utvikle, endre og legge til rette for et samarbeid med alle parter som er en del av opplæringen for elevene. Senge (2000) beskriver at det er vesentlig for deltakerne i en lærende organisasjon å ha en felles visjon og arbeide i fellesskap og dele erfaringer for å nå ulike mål. For å oppnå reell og varig endring vil det stilles krav til lærerne og lederne i skolen om å endre sitt tankesett. Et virkemiddel for å oppnå dette er at lærere får anledning til å delta på videreutdanning og at dette inngår i en helhetlig kompetanseplan for skolen. Skoleledere har et ansvar for å utvikle en delingskultur mellom disiplinene på skolen samt å legge til rette for at skolen har den nødvendige kompetansen for å kunne gi elevene best mulige tilbud. Vår studie har vist at systemisk tekning omkring delingskultur, utvikling og samarbeid mellom yrkesfaglærere, ledelse og arbeidsliv er avgjørende for at deltakere i videreutdanning kan bidra til skolens profesjonelle læringsfellesskap med visjon om å utvikle skolen som organisasjon.

\section{Forfatterbiografi}

Elin Bø Morud er universitetslektor og er i dag nesteleder med ansvar for etter- og videreutdanning ved Institutt for lærerutdanning ved NTNU. Morud er også leder av NTNU KOMPiS. Hun har jobbet mange år i skoleverket, både som lektor og skoleleder. Morud har lang erfaring fra ulike nasjonale og regionale skoleutviklingsprosjekt som UiU, SKUV, Dekom. Her har hun bidratt både som utviklingspartner og leder av prosjektene. Videre har Morud også jobbet med utvikling av flere nye studietilbud innenfor EVU, både lærerspesialistutdanninger og andre videreutdanninger rettet mot lærere, rådgivere og ledere i skolen. Forskningsinteressene omhandler tema innenfor skoleutvikling og livslang læring. 
Klara Lillevik Rokkones er førstelektor i yrkespedagogikk ved Institutt for lærerutdanning ved NTNU. Forskningsfeltet har vært knyttet til yrkesfag, yrkesfaglæreren og EVU i Yrkesfaglærerløftet. Hun har lang erfaring fra undervisning i videregående skole innenfor restaurant- og matfag samt ulike lederfunksjoner innenfor fag- og yrkesopplæring. Ved ILU er hun i dag fagseksjonsleder for yrkesfag, skoleutvikling og utdanningsledelse. I yrkesfaglærerutdanningen har hun bidratt i utviklingen av bachelorutdanning YFL, masterutdanning i yrkesdidaktikk og ulike EVU-tilbud for yrkesfaglærere. Hun har undervist og veiledet innenfor grunnutdanning, masterutdanning og EVU tilbud. Har bidratt i nasjonale nettverk i læreplanutvikling, utredningsarbeid og samarbeidet tett om utviklingen av yrkesfag nasjonalt.

\section{Referanser}

Andersson, P. \& Köpsén, S. (2015) Continuing professional development of vocational teachers: participation in a Swedish national initiative. Empirical Research in Vocational Education and Training, 7(1), 1-20. Springer Open Journal. https://doi.org/10.1186/s40461-015-0019-3

Chrzanowska, J. (2002). Interviewing Groups and Individuals in Qualitative Market Research. London: Sage Publ. Ltd. https://doi.org/10.4135/9781849209342

Bjørnsrud, H. (2015). Skolebasert kompetanseutvikling: Organisasjonslaering for delingskultur. Oslo: Gyldendal akademisk.

Bound, H. (2011) Vocational education and training teacher professional development: tensions and context. Studies in Continuing Education, 33:2, 107-119. https://doi.org/10.1080/0158037X.2011.554176

Dehlin, E. \& Irgens, E.J. (2018): Case C. I M.B. Postholm, A. Normann, T. Dahl, E. Dehlin, G. Engvik \& E. Irgens (red.), Skole- og utdanningssektoren i utvikling (s. 225-271). Bergen: Vigmostad \& Bjørke AS.

Ertsås, T.I., \& Irgens, E.J. (2012). Teoriens betydning for profesjonell yrkesutøvelse. I M.B. Postholm (red.). Lareres laring og ledelse av profesjonsutvikling (s. 195-215). Trondheim: Tapir akademisk forlag.

Ertsås, T.I. (2017). Videreutdanning av lærere: Samspill mellom ulike kunnskapsformer. I M.B. Postholm (red.), Kunnskap for en bedre skole. Etter- og videreutdanning som strategi (s. 145-159). Bergen: Fagbokforlaget.

Fontana, A., \& Frey, J.H. (2000). The interview: From structured questions to negotiated text. I N. K. Denzin \& Y. S. Lincoln (red.), Handbook of qualitative research (2nd ed., s. 645-672). Thousand Oaks, CA: Sage.

Glosvik, Ø. (2010). Systemisk tenking som grunnlag for leiing; - ein innfallsvinkel til lærande organisasjonar? Norsk Pedagogisk Tidsskrift, 94(4), 306-317.

Grutle, B.E. (2018). Profesjonsfellesskap og skoleutvikling: Laerere som laerer. Oslo: Cappelen Damm akademisk.

Hargreaves, A. \& Fullan, M. (2014). Arbeidskultur for bedre laring i alle skoler: Hva er $n \phi d v e n d i g$ laererkapital? Oslo: Kommuneforlaget.

Irgens, E. (2007). Profesjon og organisasjon: å arbeide som profesjonsutdannet. Bergen: Fagbokforlaget. 
Kamberelis, G. \& Dimitriadis, G. (2011). Focus Groups Contingent Articulations of Pedagogy, Politics and Inquiry. I Denzin, N.K. \& Lincolc, Y.S., (red.), The SAGE Handbook of Qualitative Research, Vol. 4, Sage, Los Angeles, 545-561.

Kunnskapsdepartementet. (2004). St.meld. nr. 30 (2003-2004). Kultur for laring. Oslo: Kunnskapsdepartementet.

Kunnskapsdepartementet (2015a). Yrkesfaglaererløftet. Strategi for fremtidens fagarbeidere. Oslo: Kunnskapsdepartementet.43

Kunnskapsdepartementet (2015b). Kompetanse for kvalitet. Strategi for videreutdanning for larere og skoleledere frem mot 2025. Oslo: Kunnskapsdepartementet.

Kvale, S., Brinkmann, S., Anderssen, T. \& Rygge, J. (2015). Det kvalitative forskningsintervju. Oslo: Gyldendal akademisk.

Malterud, K. (2011). Fokusgrupper som forskningsmetode i medisin og helsefag. Oslo: Universitetsforlaget.

Maugsten, M. \& Mellegård, I. (2015). Profesjonelle læringsfellesskap for lærere i videreutdanning - utvikling i kunnskapskulturen. Acta Didactica Norge, 9(1), 20. https://doi.org/10.5617/adno.2369

NESH. (2016). Forskningsetiske retningslinjer for samfunnsvitenskap, humaniora, juss og teknologi. Oslo: Norwegian National Committees for Research Ethics. https://www.etikkom.no/forskningsetiske-retningslinjer/Samfunnsvitenskap-jus-oghumaniora

NOU (2019:12). Laerekraftig utvikling — Livslang laring for omstilling og konkurranseevne. Kunnskapsdepartementet, Norges offentlige utredninger.

OECD (2014). Teaching and Learning International Survey (TALIS) -2013. Hentet 16. februar 2017 fra https://www.udir.no/tall-og-forskning/finn-forskning/rapporter/TALIS2013/

Parise, L. \& Spillane, J. (2010). Teacher Learning and Instructional Change: How Formal and Onthe-Job Learning Opportunities Predict Change in Elementary School Teachers' Practice. The Elementary School Journal, 110(3), 323-346. https://doi.org/10.1086/648981

Postholm, M.B. \& Moen, T. (2009). Forsknings- og utviklingsarbeid i skolen: Metodebok for laerere, studenter og forskere. Oslo: Universitetsforlaget.

Postholm, M.B. \& Jacobsen, D.I. (2011). Lareren med forskerblikk: innføring i vitenskapelig metode for laererstudenter. Kristiansand: Høyskoleforlaget.

Postholm, M.B. \& Rokkones, K. (2012a). Læreres profesjonelle utvikling: Videreutdanning RM og TIP. I M.B. Postholm (red.), Laereres laring og ledelse av profesjonsutvikling (s. 99119). Trondheim: Tapir akademisk forlag.

Postholm, M.B. \& Rokkones, K. (2012b). Læreres profesjonelle utvikling: En review av forskning om hvordan lærere lærer. I M.B. Postholm (red.), Laereres lacring og ledelse av profesjonsutvikling (s. 21-51). Trondheim: Tapir akademisk forlag.

Postholm, M.B. \& Rokkones, K. (2013). Videreutdanning i yrkesfaglige programfag: Læreres opplevelser av studiets betydning for egen læring og yrkesutøvelsen i skolen. Tidsskriftet FoU i praksis 7(2), 93-111.

Postholm, M.B. \& Rokkones, K. (2015). Teachers' and School Leaders' Perceptions of Further Education and Learning in School. Creative Education, 6(23), 2447-2458.

https://doi.org/10.4236/ce.2015.623252 
Postholm, M.B. (2017). Læreres opplevelse av videreutdanningens betydning for læring og praksisutøvelse i skolen. I M.B. Postholm (red.), Kunnskap for en bedre skole. Etter- og videreutdanning som strategi (s. 85-104). Bergen: Fagbokforlaget.

Postholm, M.B. (2018). Kvalitativ dataanalyse. I M.B. Postholm, D. I. Jacobsen, \& R. Søbstad, Forskningsmetode for masterstudenter i laererutdanningen (s. 139-164). Oslo: Cappelen Damm akademisk.

Rennestam, J. \& Wästerfors, D. (2015). Från stoff til studie: Om analysarbete i kvalitativ forskning. Lund: Studentlitteratur AB.

Robinson, V.M.J. (1993). Problem-based methodology: Research for the improvement of the practice. Oxford: Pergamon Press.

Robinson, V.M.J. (2014). Elevsentrert skoleledelse. Oslo: Cappelen Damm akademisk.

Rokkones, K. (2017): Kompetanseutvikling på yrkesfag. I M.B. Postholm (red.), Kunnskap for en bedre skole. Etter- og videreutdanning som strategi (s. 121-144). Bergen: Fagbokforlaget.

Sekkingstad, D. \& Syse, I. (2019). Spør oss, vi vil bidra - lærarar som lokomotiv for å fremje skuleutvikling - ein mogleg modell. Hentet fra https://fjordkonferansen.no/fjordantologien/ (lastet ned 12. september 2019).

Senge, P. (2006). The fifth discipline: the art and practice of the learning organization. New York: Double /Curransy.

Senge, P. (2000). Schools that learn. A fifth discipline Fieldbook for Educators, Parents and everybody who cares about Education: USA: Doubleday.

Stortingsmelding nr. 31. (2007-2008). Kvalitet i skolen (2008). Oslo: Kunnskapsdepartementet.

Stortingsmelding 21. (2016-2017). Larelyst - tidlig innsats og kvalitet i skolen (2016-2017). Oslo: Kunnskapsdepartementet.

Strauss, A. \& Corbin, J. (1998). Basics and Qualitative Research: Techniques and Procedures for developing Grounded Theory, $2^{\text {nd }}$ edition. Thousand Oaks, CA: Sage Publications, Inc.

Tiller, T. (2006). Aksjonslaring - forskende partnerskap i skolen: Motoren i det nye laringslфftet (2. utg. ed.). Kristiansand: Høyskoleforlaget.

Wahlstrom, K., Louis, K.S., Leithwood, K. \& Anderson, S.E. (2010). Investigating the Links to Improved Student Learning. Executive Summary of Research Findings. Hentet fra https://conservancy.umn.edu/bitstream/handle/11299/140884/Executive\%20Summary\%20R eport-Web $\% 20 \% 282 \% 29$.pdf? sequence $=1 \&$ is Allowed $=\mathrm{y}$

Aamodt, P.O, Carlsten, T.C., Caspersen, J., Grøgaard, J.B. \& Røsdal, T. (2016). Kompetanseutvikling blant yrkesfaglaerere: En undersфkelse basert på OECD Teaching and Learning International Survey (TALIS). Rapport 2016:6. NIFU og NTNU Samfunnsforskning AS. 